\title{
UCZESTNICTWO W POLSKIEJ KULTURZE IMIGRANTÓW EDUKACYJNYCH Z UKRAINY
}

\author{
CULTURAL PARTICIPATION OF THE STUDENTS \\ FROM UKRAINE IN POLAND
}

\begin{abstract}
Almost 40 thousand Ukrainians study in Poland. This is the second largest student group in our country. The main reason for them to study here is to get a diploma but an academic period is also a time of intense cultural participation. In this article I analyze the perception of culture by Ukrainians. What do art and culture mean for them? What they appreciate and what they reject in this sphere. Do they attend high culture events or they prefer popular culture? Finally, what is the difference between cultural participation in Poland and in Ukraine? This article is based on 50 qualitative interviews among Ukrainian students in Warsaw.
\end{abstract}

Key words: cultural participation; Ukrainians; students; immigrants

Streszczenie

ANNA JAWOR

Uniwersytet Warszawsk

W Polsce studiuje prawie 40 tysięcy Ukrainek i Ukraińców. Jest to największa po Polakach grupa narodowościowa studentów w naszym kraju. Przyjeżdżają oni tutaj głównie po to, żeby zdobyć dyplom, ale studia to również czas intensywnej partycypacji kulturalnej. W artykule przyglądam się postrzeganiu kultury przez Ukraińców. Jakie znaczenie przypisują kulturze i sztuce, co w niej cenią, a co odrzucają. Czy uczestniczą w kulturze wysokiej, czy popularnej. Co jest zachętą do uczestnictwa, a co stanowi bariery. W końcu, jaka jest różnica między uczestnictwem w kulturze w Polsce i na Ukrainie.

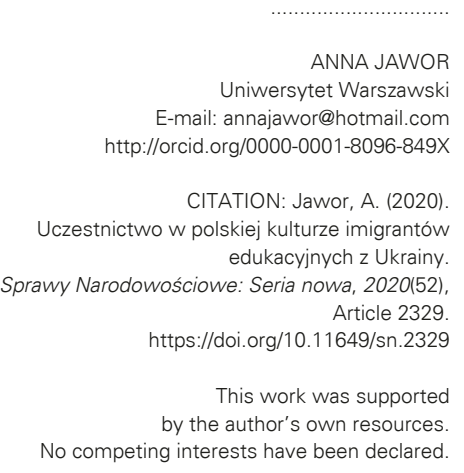

This is an Open Access article distributed under the terms of the Creative Commons Attribution 3.0 PL License (creativecommons.org/licenses/by/3.0/pl/), which permits redistribution, commercial and non-commercial, provided that the article is properly cited. (C) The Author(s) 2020

Publisher: Institute of Slavic Studies, Polish Academy of Sciences

Publishing History: Received 2020-07-07; Accepted 2020-12-13; Published 2020-12-23 
Artykuł powstał na podstawie 50 wywiadów jakościowych przeprowadzonych wśród studiujących w Warszawie.

Słowa kluczowe: uczestnictwo w kulturze; Ukraińcy; studenci; imigranci

U krainki i Ukraińcy stanowią największą grupę cudzoziemców w naszym kraju. Szacuje się, że przebywa ich w Polsce ok. 2 milionów. Ukraińcy migrują do Polski z większą intensywnością niż niedawno Polacy do Wielkiej Brytanii. Są to głównie osoby przyjeżdżające w celach zarobkowych, imigranci ekonomiczni, lecz coraz większą grupę stanowią również imigranci edukacyjni. Studenci z Ukrainy są największą po Polakach grupą narodowościową na polskich uczelniach i stanowią ponad połowę wszystkich studentów zagranicznych w naszym kraju. W roku 2018 ich liczba wynosiła 38 tysięcy, tzn. że w ciągu dekady wzrosła 18-krotnie (Raport Studenci zagraniczni, 2018).

Najczęstszymi przyczynami wyboru studiów po naszej stronie Buga są: chęć posiadania dyplomu zagranicznego uniwersytetu; poznanie świata; wyższy poziom nauczania; chęć posiadania europejskiego dyplomu, który umożliwi wyjazd na Zachód oraz większa szansa znalezienia pracy, zrobienia kariery. Jednak nie tylko pragmatyczne względy decydują o wyborze Polski. Kolejne czynniki motywujące Ukraińców do podjęcia studiów w naszym kraju to: ciekawsze życie towarzyskie, możliwość atrakcyjnego spędzania czasu wolnego oraz lepsze możliwości rozwijania swoich zainteresowań (Długosz, 2018). Studenci ze Wschodu spędzają tutaj kilka bardzo ważnych, niekiedy formujących, lat swojego życia. To czas pełen wyzwań, prób i doświadczeń na o wiele większą skalę niż zdawanie egzaminów i kolokwiów. Tymczasem brakuje badań skupiających się na innych niż studia obszarach życia tej młodzieży. Zdecydowanie brakuje danych na temat jej aktywności kulturalnej i dostępu do kultury.

Lukę tę zaczęły wypełniać badania prowadzone przez zespół w składzie Marta Jadwiga Pietrusińska, Urszula Markowska-Manista i pisząca te słowa. Na prośbę Biura Kultury Urzędu m.st. Warszawy zrealizowałyśmy pro bono badanie w celu diagnozy sposobów korzystania z oferty kulturalnej stolicy przez imigrantów, na przykładzie warszawskich studentów narodowości ukraińskiej. W 2019 roku, z pomocą polskich studentek i studentów Wydziału Pedagogicznego UW, przeprowadziłyśmy 50 częściowo ustrukturyzowanych wywiadów ze studentkami i studentami z Ukrainy. Osoby badane miały studiować różne kierunki na różnych warszawskich uczelniach i zostały dobrane metodą kuli śnieżnej. Wyniki tego badania oraz rekomendacje dla miasta są dostępne w raporcie pt. „Bariery w korzystaniu z oferty warszawskich instytucji kultury przez młodych imigrantów z Ukrainy. Diagnoza - przyczyny - rekomendacje" (Jawor i in., 2019). Rozwinięcie badań znajdą Czytelnicy w książce Konkultura. Wymiary uczestnictwa w kulturze młodych imigrantów z Ukrainy (Jawor i in., 2020). Niniejszy tekst powstał na bazie danych uzyskanych w toku tego przedsięwzięcia.

Celem tego artykułu jest wskazanie, czym dla Ukrainek i Ukraińców studiujących w Polsce jest kultura i uczestnictwo w kulturze, jakie pełnią funkcje i mają znaczenie. Ponadto, co młodzi Ukraińcy cenią w kulturze, a co odrzucają. Jaką rolę odgrywa kultura w ich życiu, co ich motywuje do partycypacji kulturalnej oraz jakie przeszkody napotykają w tym kontekście. Czy kultury wysoka i popularna jakoś różnicują ich uczestnictwo i czym jest konkultura. W końcu, jak postrzegają Polskę i Warszawę oraz jakie dostrzegają różnice między uczestnictwem w kulturze w obu krajach. 
Nasz sposób rozumienia uczestnictwa w kulturze uwarunkowany był konkretnym zapotrzebowaniem zgłoszonym przez Biuro Kultury m.st. Warszawy. Biuro interesowały bariery, jakie napotykają imigranci chcący uczestniczyć w warszawskich instytucjach kultury. Choć więc socjologowie i kulturoznawcy do uczestnictwa w kulturze coraz częściej zaliczają wszelkie relacje i praktyki, które zawsze są warunkowane kulturowo, takie jak nawyki żywieniowe, wystrój mieszkania czy uprawianie ogrodu (zob. np. Drozdowski i in., 2014), na potrzeby naszego badania przyjęłyśmy klasyczne rozumienie uczestnictwa pojmowanego jako korzystanie z zasobów kultury tworzonych przez instytucje kultury.

\section{KWESTIA SMAKU}

Jest wiele definicji uczestnictwa w kulturze, na potrzeby tego badania przyjmujemy wąskie rozumienie jako kontakt ze sztuką, udział w wydarzeniach artystycznych (koncertach, spektaklach, wystawach...), odwiedzanie instytucji kultury. Instytucje kultury to są miejsca upowszechniania kultury, w których odbywają się wydarzenia artystyczne; takie miejsca, jak teatry, kina, galerie sztuki, muzea, filharmonia, orkiestry, biblioteki, domy kultury

- to fragment scenariusza wywiadu, w którym informujemy rozmówców jak na potrzeby badania pojmujemy uczestnictwo w kulturze. Badani wychodzili jednak poza nakreślone ramy, poszerzając aktywności, miejsca i zdarzenia artystyczne o sfery rozrywki, rozwoju i rekreacji. Pytani o kulturę, rozmówcy niejednokrotnie wymieniali takie czynności, jak spotkania w kawiarniach, spacery w parku, imprezy w klubach tanecznych, wydarzenia naukowe (wykłady otwarte), i sportowe (np. mecze piłki nożnej). Kulturę rozumieją zatem szeroko. Nie jest to najszersze ujęcie kultury, do którego należą prawie wszystkie aktywności ludzkie, które zawsze są warunkowane kulturowo (zob. Burszta, 1998). Jest to jednak coś więcej niż uczestnictwo w kulturze instytucjonalnej, które było de facto przedmiotem naszego zainteresowania $w$ tym badaniu.

Uczestnictwo w kulturze jawi się jako atrakcyjny sposób spędzania wolnego czasu, służy rozrywce, a więc, jak wskazuje etymologia tego wyrazu, rozerwaniu bezpowrotnie upływającego czasu; zatrzymaniu go i spędzeniu inaczej niż zwykle. Badani podkreślają też rolę spotkań i budowania więzi przy okazji partycypacji kulturalnej:

No to jest forma rozrywki, bardzo różnorodnej. Można dostosować to do upodobań i to jest doskonała forma spędzania czasu z innymi ludźmi i integrowania się [...]. Ja z moją mamą bardzo lubimy gdzieś razem wychodzić i często właśnie chodzimy do teatru czy do kina. Od dziecka mama mnie zabiera na balet, jeśli gdzieś jest więc to jest nasza forma spędzania wolnego czasu (A_K_8).

Niemniej, uczestnictwo w kulturze ma także bardziej wzniosłe funkcje. To nośnik tożsamości, przestrzeń ocalania, utrwalania i podtrzymywania przy życiu tradycji, zwyczajów i innych elementów uniwersum kulturowego. Kultura służy również zaznaczaniu specyfiki i odrębności Ukrainek i Ukraińców, wyrażającej się przede wszystkim w folklorze. Od ogłoszenia niepodległości przez Ukrainę w 1991 roku szczególny akcent w wychowaniu młodzieży położony jest na kontakt z kulturą narodową i tradycjami narodowymi. Młodzi ludzie mają uświadamiać sobie swoją przynależność narodową, rozwijać stosunek emocjonalny do kultury i historii ojczyzny oraz do języka ukraińskiego. Podstawowymi zasadami działalności placówek edukacyjnych są zasady wychowania narodowego, z których 
do najważniejszych zalicza się: „ludowość wychowania” (nauczanie języka ojczystego; kształtowanie świadomości narodowej, miłości do ziemi ojczystej i narodu; wszczepianie szacunku do kultury, dziedzictwa narodowego i tradycji, a także kultury i tradycji wszystkich narodów zamieszkujących Ukrainę) oraz „wychowanie zgodne z kulturą" (akcentowanie związku z historią narodu, jego językiem, tradycjami kultury i życia codziennego, sztuką ludową, rzemiosłem; tworzenie wspólnoty duchowej i łączności pokoleniowej) (Jędraszczyk i in., 2016). Studentki i studenci z Ukrainy w Polsce starają się pielęgnować to, czego nauczyli się w swoim kraju pochodzenia. I tak nasze badane opowiadają:

Czytamy książki (dużo książek), słuchamy muzyki - właśnie takiej nie współczesnej, tylko takiej bardziej ludowej. W szkole byłam w chorze, gdzie śpiewaliśmy bardzo dużo takich piosenek ukraińskich - ludowych i takich trochę na tematy religijne i właśnie działalność takich chórów i takich zespołów tanecznych, ludowych jest bardzo rozwinięta w szkołach, poza tym (nie wiem, jak tutaj to jest, ale) będąc uczniem, to każdy jest zobowiązany przynajmniej 2-3 razy w roku, oprócz Dnia Niepodległości, chodzić w takiej koszulce wyszywanej - w takiej ukraińskiej, na jakieś rożne tam święta szkolne, święta takie państwowe - to jesteśmy tak zobowiązani, a również język ukraiński - w takim kontekście, jak to teraz brzmi u nas w państwie - to zawsze robiliśmy tak, że musiałeś najpierw chodzić na takie konkursy rożne dotyczące języka ukraińskiego - to był obowiązek, to nie ma tak, że chcesz, czy nie chcesz, tylko musisz iść. Ale to nie było tak, że z niechęci tylko raczej tak. I rożne takie wieczory literatury ukraińskiej na rożne temat - musiałyśmy (właśnie: musiałyśmy, bo bardziej to dziewczyny były niż chłopaki) przygotowywać takie rożne scenki, uczestniczyć w świętach, organizować jakieś takie wieczory. [...] Tak już biorąc globalnie bardziej, to bardzo dużo daje dla tożsamości narodu. Po pierwsze, właśnie to, że - szczególnie jak się tworzy w języku, prawda? Ojczystym. No... dużo daje (M_K_2).

Obyczaje i tradycje danej kultury, rozwój i popularyzacja pieśni narodowej, tańca, literatury (U_K_4).

Po prostu jeśli będziemy chodzić na takie koncerty czy coś takiego, to my będziemy pamiętać, że my mamy takie kulture ukraińskie, że mamy to to i mamy tańce, takie ubrania. A jeżeli nie to my nie będziemy pamiętać i dzieci i tak dalej i dalej, nie możemy powiedzieć, że tak było i nasza kultura może zginąć (A_K_10).

Abstrahując od problematyki, domeną kultury przede wszystkim jest to, aby poruszać człowieka emocjonalnie i duchowo. Kultura jawi się jako sfera uczuć, przeżyć, duchowego i emocjonalnego spełnienia. Jak mówi jedna z badanych:

Kiedyś się zastanawiałam, jakie jest praktyczne znaczenie kultury w życiu człowieka. I dla mnie to było zmuszać człowieka się zastanowić i poczuć jakieś emocje, swego rodzaju buntować się. Dlatego ja uważam, że najlepsze filmy, książki, wiersze, sztuka ogólnie to jest ta, która zrobiła na mnie jakieś wrażenie większe, wywołała we mnie emocje. Czy to pozytywne, czy to negatywne nie ma to znaczenia, ważne, że wywołała u mnie jakieś emocje (A_K_2).

Kultura to również przestrzeń poznawania nowych treści, poszerzania horyzontów, wzbogacająca intelektualnie. To sfera porządkująca widzenie świata, dająca narzędzia do pewniejszego poruszania się w nim i do sprawniejszej komunikacji między ludźmi. Badani podkreślają różnicę między żywą sztuką, której można namacalnie, „tu i teraz” doświadczyć, a tą zapośredniczoną medialnie, która nie zapewnia takiej jakości ani intensywności przeżycia. Ta różnica ujawnia się choćby w porównaniu teatru i kina:

Kino dla mnie jest zbędne. Przez ekran jakby, ten sam ekran mam w domu na laptopie, no więc jakby nie odczuwam żadnego (...) większej różnicy w sumie. [...] Ja na przykład bardziej lubię dramy w teatrze oglądać (A_K_12). 
Co ciekawe, teatr dramatyczny utożsamiany jest z kulturą, ale już komedie, choćby grane $w$ tych samych teatrach, przez tych samych aktorów, jawią się jako rozrywka (nie kultura), gdyż - jak mówi jeden z rozmówców - „nie mają sensu”. Żeby dzieło zakwalifikować do kultury, żeby zasłużyło na nobilitację, jaką jest wystawianie go na scenie, musi mieć ono głębszy sens. Kultura to nie jest więc dziedzina przeżyć lekkich i przyjemnych, ma poruszać, ale te najgłębsze pokłady tych mroczniejszych zakamarków duszy. Kultura sublimuje też ludzkie cierpienie, daje odetchnąć, dodaje otuchy. Kultura łagodzi obyczaje. Osoby uczestniczące w życiu kulturalnym są spokojniejsze, wrażliwsze, szczęśliwsze. Jeden z badanych mówi:

Że jak osoba, no niestety ja nie jestem taką osobą, ale jak osoba wzbogaca się kulturowo, to to jest dobrze. Uważam, że ona wtedy robi się nie taka agresywna, nie, nie... patrzy na świat przez jakiś inny pryzmat, taki mniej negatywny. I na przykład, no teraz oczywiście myślę, że ta kultura w życiu Ukraińców, ewentualnie, pomaga im zapomnieć o tej wojnie, która jest na Ukrainie. Może chodzą do teatru i jakoś wzbogacają się kulturowo i jest im dobrze (M_M_1).

Uczestnictwo w kulturze pozwala przenieść się w inny świat, świat innych emocji, ale też zmusza do namysłu. Pozwala przefiltrować inną rzeczywistość i wrócić do siebie wzbogaconym o ten nowy wymiar. Dlatego dla respondentów ważny jest splot świata przedstawionego w dziele artystycznym z rzeczywistością „tu i teraz”. Badani szukają takich paraleli, kiedy nawet abstrakcja pomaga lepiej odnajdywać się w życiu codziennym. To by było po myśli klasyków polskiej pedagogiki społecznej i socjologii kultury (zob. Grad, 1997), dowodzących, że uczestnictwo w kulturze czyni nas ludźmi bardziej otwartymi, o większej wyobraźni, bardziej krytycznymi, ale też łatwiej adaptującymi się do zmieniającej się rzeczywistości. Pozwala w bezpiecznym kontekście przygotować się na inną sytuację życiową, pomaga również oswajać się z innością. Nasi rozmówcy mówią o tym tak:

Każda rzecz, która jest wytworzona przez człowieka właśnie w takiej działalności umysłowej, która zmusza każdego innego, by pomyśleć o czymś - tak kreatywnie, tak inaczej, spojrzeć na problem z innej strony - to jest sztuka, moim zdaniem. Może takie obciachy też są potrzebne, i to bardzo, ponieważ dobrzy artyści też patrząc na takie coś, to tak sobie myślą o tym i tak się zastanawiają, i to pobudza jakieś myślenie właśnie. [...] Właśnie w sztuce nie chodzi o to, żeby stworzyć „coś", tylko coś, co daje jakąś wartość, coś, co zmusza myśleć inaczej (M_K_2).

Wartościowe uważam, że sztuka jest w stanie pokazać nam jakiś inny stan świadomości, czyli pozwala nam wejść w cudze buty w cudzysłowie i poczuć się na miejscu kogoś, kto nie ma takiego samego losu jak my kto przeżywa coś innego tak poczuć coś co normalnie człowiek by nie przeżył tak, bo jak na przykład oglądamy filmy wojenne, to mam nadzieję nigdy nie doświadczymy wojny w znaczeniu jakby bardzo dosłownym, ale możemy też to przeżyć w jakiś sposób więc takie reflektowanie a nie się za pomocą sztuki To jest bardzo dobre, też fajne jest to pokazuje różne poglądy ludzi na świat, może to na nas jakoś wpłynąć, czyli zmienić nasze priorytety albo zmusić nas do namysłu nad jakąś rzeczą także głównie to, że sztuka nam coś pokazuje. Nawet jeżeli to jest czytanie jakiejś książki po prostu wiersza zawsze to się jakoś odbija [...] wartościowe to jest zainspirowanie kogoś też do stworzenia czegoś swojego pokazanie jakiś innych poglądów życiowych emocji (U_K_1).

No nie wiem, na przykład jak idę do jakiejś galerii sztuki, to staram się znaleźć coś pomysłowego, w sensie coś w czym można znaleźć jakiś sens, który, co ma związek z teraźniejszością, z jakimiś tam nie wiem, aktualnymi problemami i jak widzę to jakby cieszę się z tego, że mogę odnaleźć jakiś związek pomiędzy sztuką, a realnością, tzn. rzeczywistością (A_M_2).

Studenci i studentki z Ukrainy są dosyć konserwatywni, jeśli chodzi o gust estetyczny. Cenią klasykę, akademizm, weryzm w sztuce. Sztuka współczesna jest przez wielu z nich 
niedoceniania, niezrozumiana, postrzegana wręcz w kategoriach kiczu. Dla zilustrowania tego zjawiska warto przytoczyć kilka wypowiedzi:

Więc jeżeli chodzi o wartościową to jest na pewno to sztuka z przeszłości, czyli jakieś stare filmy takie starsze; też obrazy... bardzo lubię epokę renesansu, impresjonizmu. Co jeszcze...? Jeśli chodzi o książki to też takie starsze i autorzy - Edgar Allan Poe, Antoine Saint Exupery, Szekspir też jest fajny mimo że może ciężko się czyta czasem; więc takie bardziej rzeczy z przeszłości (U_K_1).

Ale tak szczególnie to nie wiem czy wyróżnitbym jakiś nurt, no ale ekspresjonizm jest fajny, tak jak popatrzę na to wszystko... (A_M_2).

To znaczy tak, lubię jakieś piękne obrazy, cos takiego, bardziej galerie, ale dziwi mnie to, co w kulturze teraz się odbywa. Znaczy takie jakieś dziwne rzeczy, na przykład jak to było, cos tam było na studiach, bo chodziłam na tabu w sztuce tutaj na wydziale i tam mięliśmy takie zajęcia i jak nam pani pokazywała rożne dzieła sztuki.

- Nowoczesne?

- Tak tak, to było takie dziwactwo, jakieś gówno w puszkach, co to w ogóle jest? No i to się sprzedawało za takie miliony i takie dziwne dzieła, dziwnie na nie patrzę (M_K_7).

Czego nie rozumiem w kulturze - samookaleczenie w celu wyrażenia siebie, swojej myśli (U_M_1).

A kiczowate uważam poniekąd współczesną sztukę, dlatego że ona przez to, że próbuje się wybić za jakieś ramki stworzone wcześniej, tak... No bo wcześniej coś było sztuką albo nie było jakby dwa takie pojęcia, natomiast dzisiaj wszyscy starają się to rozmyć, że nawet... nie wiem kamień leżący pośrodku pokoju to może być sztuka. Natomiast dla mnie nie zawsze ten przekaz jest jasny, więc uważam, że nadużywanie metafor i jakieś współczesne przedstawienie, w którym nie da się dostrzec jakiegoś jasnego sensu to dla mnie to jest kiczem. [...] ja na przykład nie jem mięsa; lubię kiedy ludzie zwracają uwagę nanoszenie futra czy spożywanie mięsa z nieekologicznych źródeł to jest fajny cel. A kiedy ludzie po prostu, no nie wiem chodzą na golasa, bo po prostu im się chce albo chce się powykrzykiwać jakieś hasła, uważam, że to jednak nie jest sztuka. Może to takie stereotypowe może "starożyckie”, ale tak mi się wydaje (U_K_1).

Jednak zdarzają się i takie głosy, że sztuka traci na wartości wraz z upływem czasu, że klasyka (np. opera) jest już za stara. Kino, jako medium stosunkowo nowe (niewiele ponad sto lat) jest tu postrzegane jako postępowe, a więc wartościowe. Kino to w końcu taka forma sztuki, która przez swoją masowość, ma większe niż każda inna działalność artystyczna możliwości wpływu na społeczeństwo. Zasługuje więc na uznanie za zaangażowanie społeczne, za to, że ma potencjał zmiany normatywnej, poruszania sumień, który jawi się jako kolejny walor uczestnictwa w kulturze.

Co cenię w kulturze? Właśnie chciałam przytoczyć przykład tego, co się ostatnio stało w takim dyskursie społecznym, dostownie w okresie ostatnich paru dni. Film braci Sekielskich, dokumentalny. Myślę, że jest to bardzo fajna inicjatywa, nie wiem czy kulturalna, ale na pewno związana z publicystyką, z dokumentem, więc jest to rzecz, którą cenie, ponieważ jest to inicjatywa oddolna, finansowana przez współobywateli, czyli może jakieś zaangażowanie ludzi w jakąś formę przemian ustrojowych, ale też kulturowych, bo myślę, że to może do tego dojść (M_M_2).

Nie każdy model zaangażowania jest akceptowalny dla badanych. Razi, na przykład, wykorzystywanie symboli narodowych w takiej działalności (pseudo)artystyczno-propagandowej. Symbole narodowe są jak sacrum, odrębny porządek i nie ich miejsce na tatuażach czy murach, gdzie są pozbawione należytego kontekstu. Za kiczowate uchodzą też niektóre realizacje będące $w$ założeniu estetycznym hołdem oddawanym politykom czy zdarzeniom politycznym. 
Co mi się nie podoba? Hmm tutaj też jest bardzo duży przykład. Nie podoba mi się jak w przestrzeni publicznej dewastowane są symbole narodowe i w jaki sposób są ukazywane... Mogę tutaj wspomnieć o tatuażach Polski Walczącej na kibicach, czyli przedstawianie ich w takiej patetycznej odsłonie, jakaś zakrwawiona flaga, jakiś wilk wyjący, biały i goła kobieta... Myślę, że te rzeczy nie są przeznaczone na tego typu eksponowanie, noszenie ich. A druga sprawa to na przykład już tak bardzo konkretnie to pomniki Lecha Kaczynskiego, moje ulubione (śmiech) i przykład też takiej sztuki smoleńskiej, powstałej po katastrofie smoleńskiej. Jest taki artysta Dowiagło, który bardzo się realizował w tym temacie i w kościele na Dewajtis jest bardzo fajny przykład na to jak nie powinna wyglądać sztuka. Właśnie taki obraz przedstawiający wybuch samolotu. Myślę, że to jest kwintesencja kiczu (M_M_2).

Tymczasem badani zwracają uwagę na jakość oferty kulturalnej. Jeśli nie spełnia ona ich oczekiwań, nie jest postrzegana jako wartościowa, nie korzystają z niej.

Ewentualnie czy są to jakieś przedstawienia, czy wydarzenia kulturowe i są kiczowe, no to nie pójdę (U_K_1).

Co zatem zachęca do uczestnictwa w kulturze w Polsce?

\section{UCZESTNICTWO W KULTURZE}

Większości ukraińskich studentek i studentów nie trzeba specjalnie motywować do uczestnictwa w kulturze. Kultura stanowi dla nich ważną część życia, mają potrzebę obcowania ze sztuką i pięknem (co dziesiąty z naszych badanych sam zajmował się twórczością artystyczną w swoim kraju). Niewątpliwą zachętę stanowi natomiast fakt, że jest to doskonały sposób na poznanie polskiej kultury. Przez uczestnictwo w kulturze imigranci poznają Polskę, jej historię i dziedzictwo kulturowe. Daje się wyczuć wręcz poczucie wewnętrznego obowiązku, aby zdobywać wiedzę o polskiej historii, a także rozumienie i docenianie wagi kultury w integracji z nowym krajem i jego mieszkańcami. Badani do tego stopnia starają się przyswoić polską historię i topografię, że organizują wycieczki swoim bliskim, którzy przyjeżdżają tutaj ich odwiedzić. Opowiadanie o swoim nowym miejscu zamieszkania również jest formułowane w postaci pewnej powinności, w kategoriach kultury osobistej. Ilustruje to kilka wypowiedzi:

Dla mnie to jest bardzo ważny element życia codziennego. No niestety tak jak mówię nie moge poświęcić więcej czasu, ale zawsze jak przechodzę mimo jakiegoś pięknego teatru, opery albo muzeum to odhaczam sobie w myślach, że chciałabym tutaj zajrzeć i na pewno to zrobię jak skończę studia. Zawsze stawiam sobie taki próg, że jak to się skończy to już zacznę tutaj to wszystko oglądać (U_K_1).

Trzeba zaangażować Ukraińców do historii, żeby ludzie, co tu mieszkają wiedzieli, co to jest za państwo, jaka jest tu kultura i chyba może lepiej będzie porozumienie między nami. [...] Chyba kino, teatry [...] I jeżeli myśleć po co tam chodzą, to po to, żeby poznać tę kulturę, żeby zrozumieć to o czym mówitem wcześniej, żeby zrozumieć, jak to wszystko wygląda (M_M_7).

No właśnie, może trochę częściej chodzę, bo tutaj jest nie wszystko zwiedzone przeze mnie i mi ciekawa jest po prostu pozwiedzać, czegoś się dowiedzieć (M_K_1).

Też często do mnie przyjeżdżali znajomi z Polski i tak dalej. No to też, nie wypadało im nie oprowadzić i nie zrobić wycieczki. Ja bez jakiejś nie wiadomo zagłębianie się w historię czy coś potrafiłam robić wycieczki niemalże na dwa dni (A_K_1). 
Wydaje mi się że właśnie w tym okresie wiosenno-letnim bardzo chętnie uczestniczą w różnego rodzaju koncertach i imprezach otwartych właśnie typu Juwenalia. Oprócz tego chętnie zwiedzają muzea, co też się zaskoczyłam, lubią poznawać na przykład historię polską, bo dla nich jest to coś niezwykłego, wszyscy są zdziwieni tak naprawdę, jak bogatą historię mają Polacy, może też troszkę zazdroszczą tego, że tak naprawdę Polacy starali się być tak niezależnym narodem i to może ich troszeczkę... z jednej strony są... może taka trochę zazdrość nie wiem, jak to ująć w stowach (M_K_6).

Uczestnictwo w kulturze jest formą atrakcyjnego spędzenia wolnego czasu, pielęgnowania kontaktów towarzyskich, jak również radzenia sobie z samotnością i poczuciem odosobnienia w nowym kraju. Bywa też obowiązkiem studenckim. Młodzi imigranci muszą brać udział w różnych wydarzeniach w ramach studiów, są z tej aktywności rozliczani, czasem mają poczucie, że ich wybrany, humanistyczny czy artystyczny, kierunek studiów zwyczajnie zobowiązuje do bycia na bieżąco z kulturą. Zdarza się i tak, że pierwotny obowiązek owocuje fascynacją i ujawnieniem się potrzeby i potencjału dalszej partycypacji kulturalnej.

Ostatnio była, jak to nazwać, prezentacja ukraińskich malarzy, malowali obrazy na tematy religijne i było bardzo fajnie, chodziłam mimo, że musiałam, takie miałam zadanie na studiach, to bardzo mi się spodobało (A_K_14).

Niektóry pasjonują się jakąś konkretną dziedziną działalności artystycznej, śledzą wydarzenia z nią związane i starają się, na miarę swoich możliwości, we wszystkich uczestniczyć. U innych decyduje przypadek. Jeśli akurat natkną się na coś, co może ich zainteresować, to próbują.

A, bo akurat spacerowaliśmy tam obok na Wiśle i patrzę, takie fajne muzeum nowoczesne, czemu nie. I tak zdecydowaliśmy z kolegami, że warto tam pójść więc. Bardzo ciekawa wycieczka w sumie wyszła z tego wtedy (M_M_5).

Zachęca też bezpłatny dostęp do danej atrakcji kulturalnej. Łączy się to z naturalną motywacją, jaką jest ciekawość. Efekty są jednak różne. Jak pokazują doświadczenia badanych, u jednych ciekawość ta zostaje zaspokojona i przechodzi w rozczarowanie, u innych staje się oczarowaniem i zostaje dopiero rozbudzona.

Właśnie byłam prawie we wszystkich muzeum, ale na tym kursie przygotowawczym, bo tak naprawdę dla osób, które mają kartę Polaka wszystkie muzeum są bezpłatne. [...] Dlatego zobaczyłam już wszystkie muzeum i nie jest to zbyt ciekawe, już widziałam, tak pierwszy raz zobaczyć to coś ciekawego, ale drugi już nie pójdę (M_K_12).

Myślę, że tak, bo ja zaczęłam częściej odwiedzać muzea i wystawy, bo tak jak wcześniej mówiłam są niektóre dni bezpłatne w muzeach i z tego naprawdę korzystamy. Studiujemy, pracujemy, ale nie mamy wystarczająco środków, żeby wydawać na takie inne atrakcje, więc korzystamy z tej możliwości. [...] Nie tylko dlatego, że to jest bezpłatne, ale jest też ciekawe i mamy chęć. Dlatego czekamy na ten dzień i idziemy do muzeum (M_K_17).

Cena biletu to jedna z barier uczestnictwa w kulturze młodych imigrantów z Ukrainy. Mimo że instytucje kultury oferują różnego rodzaju zniżki dla studentów, wciąż jest tu relatywnie drożej niż za wschodnią granicą. Chociaż tu Ukraińcy zarabiają więcej niż u siebie, mogą więc więcej wydawać, opór może wywoływać stosunek cen usług kulturalnych do innych towarów czy usług w Polsce i na Ukrainie. W kijowskiej Operze Narodowej Ukrainy bilety na "Jezioro Łabędzie" zaczynają się od 50 hrywien, to jest 7,50 zł, a kilkanaście najbardziej ekskluzywnych miejsc kosztuje 1000 hrywien (niecałe 150 zł). Dla porównania w warszawskim Teatrze Wielkim - Operze Narodowej bilety kosztują od 30 
do 350 zł. Nawet uwzględniając zniżkę studencką (20 proc.), jeśli ktoś woli skromniejsze, ale tańsze miejsca, to na Ukrainie może je kupić wielokrotnie taniej. Kultura na Ukrainie jest również relatywnie tania w stosunku do innych dóbr, np. bilet do Teatru Narodowego we Lwowie to cenowy ekwiwalent piwa w modnej kawiarni. W Warszawie bilet do teatru kosztuje tyle co 5-15 piw. Zwłaszcza właśnie, tak lubiane przez Ukraińców, teatry i kina są postrzegane jako relatywnie drogie, szczególnie w porównaniu z Ukrainą.

Powiem tak, że na Ukrainie są tańsze bilety do kina i do teatru to jest na $100 \%$, bo też kiedyś porównywałam sobie ceny. Na przykład, że bilet do kina może kosztować tam 10 złotych i nieważne, czy jesteś studentem, czy jesteś dorosłym, po prostu 10 złotych dla wszystkich. A na przykład w Polsce to jest tak: dla studenta jedna cena, dla dorosłego druga cena, dla tego inna. I masz różne ceny dla wszystkich, a tak na Ukrainie to jest tańsze i dla wszystkich równo, jednakowo (M_K_9).

Tak, zwłaszcza jeśli chodzi w Operze Narodowej, czy w Filharmonii, nawet w niektórych teatrach bardzo takich klasycznych. Dlatego że ja kiedyś chciałam Sylwestra spędzić chyba w Filharmonii, myślę to był jakiś bal bardzo ładnie, kulturalnie, ale no niestety ta cena mnie powalała, bo to było jakieś 250 zł bez żadnego cateringu, jakby no więc trzeba było jeszcze odpłacać i to mnie odtrącito. (U_K_1).

Tak, ja nie chodzę tutaj do kina, ponieważ tutaj jest drogo. Nie, ja rozumiem, że to jest jakby wykupienie praw autorskich, pokazywanie tego filmu ze względów komercyjnych, ja to wszystko wiem, bo ja tego uczyłam się. Ale czasami chciałabym jakby mieć jakąś zniżkę na to oglądanie tych filmów trochę może większą, czy jeżeli ona jest... [...] Ja byłam jeden raz tutaj w kinie, no i mi tego wystarczyło, ponieważ to jest trochę drogo. W Ukrainie to jest taniej i u nich jeszcze oprócz tego jest 30\% zniżki, jeżeli jesteś studentem. Czyli oni płacą jeszcze mniej niż jest tamta cena, ale to jeszcze zależy od tego kina, jakie jest, ponieważ są takie kino-teatry, kina, gdzie jest trochę silna taka, silniejsza jakość ekranu i dlatego jest droższy. A jest takie zwykłe, które są tańsze, to jest po prostu taka zasada tej jakości, czegoś takiego (M_K_11).

Obok bariery finansowej, która łączy się też z nawykiem przeliczania złotówek na rodzimą walutę, bo zawsze wychodzi niekorzystnie, oraz z chęcią zaoszczędzenia części zarobionych w Polsce pieniędzy, najpoważniejszym problemem jest brak czasu. Łączenie studiów z pracą, a to dotyczy znakomitej większości studiujących w Polsce Ukrainek i Ukraińców, skutecznie uniemożliwia pełne korzystanie z oferty kulturalnej. Zwłaszcza sztywne godziny pracy czy praca w godzinach popołudniowych i wieczornych, kiedy odbywa się większość wydarzeń kulturalnych, blokują do nich dostęp. Z kategorią czasu związane są też konkurencyjne aktywności, takie jak zobowiązania rodzinne i przyjacielskie czy prace domowe. Również zmęczenie i brak sit, a więc potrzeba wygospodarowania czasu na odpoczynek bierny, są poważnymi czynnikami związanymi z barierą czasową.

Na przykład godziny mogą być nie do końca zgodne, jeśli tam pracuję na przykład pierwszą połowę dnia, przykładowo coś do czwartej to nie zawsze student do takiej godziny... Znam studentów, którzy tylko o piątej kończą zajęcia: od rana do wieczora (A_K_1).

- Czy duża część Ukraińców z Warszawy Twoim zdaniem nie uczestniczy w kulturze?

- Chyba tak, bo to jest to kwestia tego czy są to studenci, czy pracują. To od tego zależy. Ale z tego co zauważyłam no to czasami oni wolą iść do jakiegoś baru niż na jakiś koncert czy wystawę? (A_K_7).

Jeśli chodzi o mnie, to na pewno brak tego czasu wolnego, tak i po prostu możliwości przeznaczenia na to mojej uwagi bo skupiam się na innych zobowiązaniach (M_K_6).

To jest chyba brak czasu, dlatego że jak człowiek przyjeżdża, to albo studiuje, albo pracuje, nie ma czasu w tygodniu żeby odpocząć, nie wiem zrobić takie sprawy domowe, zrobić jedzenie (M_M_7). 
Zdaniem badanych język stanowi blokadę dla ich rodaków, chociaż jest to raczej blokada psychologiczna. Niektórzy wstydzą się akcentu czy też obawiają, że mówią niepoprawnie pod względem gramatycznym czy stylistycznym. Im dłużej badani mieszkają w Polsce, tym znaczenie blokady językowej słabnie, jednak pełna percepcja spektaklu teatralnego czy spotkania autorskiego z poetą, nie jest tu dla wszystkich możliwa. Najtrudniejsze do pokonania jest bowiem nierozumienie polskiego kontekstu kulturowego, dziedzictwa, toposów, symboli właściwych kulturze polskiej, które ciągle powracają również w sztuce współczesnej. Tymczasem jak podkreśla Anna Przecławska w swoim klasycznym dziele, recepcja kultury zachodzi wówczas, gdy występują „dwa jej elementy: zrozumienie sensu nadawanych treści i dokonanie ich osobistej interpretacji” (Przecławska, 1976, s. 205).

Właśnie jest bardzo dużo wydarzeń polskiej kultury, bo to jest Polska, to wiadomo. Są pewne rzeczy, które rozumieją tylko Polacy, ponieważ tutaj się wychowywali, to jest jasne, ale tak to jest wszystko otwarte, chcesz - rozumiesz, nie chcesz - nie rozumiesz. [...] Tylko po prostu albo nie ze zrozumieniem, że... ja na przykład nie czytałam ani literatury, ani nie oglądałam żadnych bajek polskich, to mniej rozumiem tego wszystkiego, ale nie ma tak, że nie rozumiesz, to nie idziesz (M_K_2).

Szczególnie teatry. Teatry, coś takiego, żeby to było nie tylko w polskim humorze. Bo on jest trochę dla nas niezrozumiały (M_K_11).

Uczestnictwo w kulturze utrudnia również brak towarzystwa, część badanych żali się, że nie ma z kim wyjść. Poza tym domatorstwo, brak nawyku uczestnictwa w kulturze, brak świadomości wagi tego rodzaju praktyk czy też zwykłe lenistwo jest tu przeszkodą. Lenistwo to określenie wartościujące, formułowane jednak przez samych badanych. Ale brak partycypacji kulturalnej w mieście to może być też kwestia introwertycznej natury i preferencji bardziej kameralnych i/lub zapośredniczonych medialnie form uczestnictwa, jak czytanie książek czy oglądanie filmów na komputerze.

No to, może być tak, istnieje jakaś bariera w języku albo jakaś bardziej psychologiczna, że nie chce mu się albo jakiejś grupie osób utrzymywać kontaktu dłuższego z ludźmi i no jest taką osobą zamkniętą na przykład. Albo to też mi się wydaje, że to wszystko wypływa z typu osobowości, jak już mówitem. I w Ukrainie to też. Jeśli tu nie chodzi on to w domu też nie będzie chodzit. To nie zawsze zależy na tym, że po prostu Polacy Ukraińcy i różne narodowości (A_M_3).

Owszem, introwerci mogą na przykład nie chcieć udzielać się w takich rzeczach, ale to ich jakby sprawa. Mam koleżankę w Krakowie, która nie integeruje się w taki sposób nigdzie, bo jest po prostu introwertyczką. Uwielbia siedzieć w domu, czytać książki, oglądać seriale i tak dalej. To dla niej idealnie spędzony czas (A_K_1).

Badani zwracają uwage na rolę kapitału kulturowego wynoszonego z domu rodzinnego. Osoby, które go nie wyniosły, nie mają nawyku uczestnictwa.

Mi się wydaje, że to z wychowania. Z dzieciństwa, jeżeli chodzą z rodzicami gdzieś tam do teatru do kina, to oni bardziej polubią tą sprawę i w przyszłości też będą chodzić. Tak ja myślę (M_M_4).

Jeśli w domu nigdzie nie chodzit, to raczej nie będą chodzić w Polsce (M_K_16).

Jeśli chodzi o bariery instytucjonalne, to największą bolączkę stanowi brak informacji, brak skutecznej promocji wydarzeń. Niejednokrotnie studentki i studenci z Ukrainy w ogóle nie wiedzą, że dane instytucje istnieją, a wydarzenia się odbywają. Niektórzy badani zwracają uwagę na podziały grupowe, trzymanie się „swoich" i trudności w przenikaniu 
się grup narodowościowych. Może to generować wątpliwości, czy polska oferta kulturalna jest również dla nich, czy mogą być jej prawomocnymi odbiorcami i uczestnikami.

Niejednoznaczne jest odczucie dotyczące dyskryminacji. W większości dominuje poczucie braku bariery kulturowej, łatwej asymilacji do polskich warunków, badani nie dostrzegają segregacji w sferze kultury, widoczne są natomiast silne oznaki wykluczania, wręcz poczucia zagrożenia, braku bezpieczeństwa, podczas niektórych wydarzeń sportowych i niestety świąt państwowych.

\section{KONKULTURA}

Podczas badania sprawdzałyśmy między innymi to, jakie konkretnie miejsca odwiedzają i w jakich wydarzeniach biorą udział młodzi Ukraińcy. Zauważyłyśmy, że uczestnictwo w kulturze polskiej wśród badanych opiera się przede wszystkim na uczestnictwie w kulturze wysokiej', czyli chodzeniu do muzeów, teatrów, na zwiedzaniu zabytków. Z kolei kultura ukraińska w Warszawie, o której wspominali nasi rozmówcy, to przede wszystkim kultura popularna: spotkania ze znanymi ukraińskimi pisarzami, koncerty zespołów ukraińskich, imprezy klubowe, filmy czy stand-upy. Ta obserwacja i jej dalsze zgłębianie doprowadzity nas do skonceptualizowania i zoperacjonalizowania zjawiska konkultury (Jawor i in., 2020).

Z konkulturą mamy do czynienia wówczas, gdy grupa mniejszościowa, jak imigranci z Ukrainy w Polsce, adaptuje się do życia w nowym kraju, uczestnicząc w kulturze wysokiej, poznając kanon polskiej kultury narodowej (Kurczewska, 2000), ale nie integrując się z Polkami i Polakami. Poznanie kultury wysokiej nie służy współuczestnictwu, gdyż imigranci nie mają (jeszcze) kompetencji, nie czują kontekstu, żeby jej doświadczać tak jak Polacy albo tak jak kulturę popularną. Dlatego nie przeżywają jej, nie angażują się emocjonalnie, tak jak w przypadku swojej rodzimej kultury. Jednocześnie ci sami Ukraińcy integrują się z innym Ukraińcami (a separują od Polaków), uczestnicząc we własnym gronie w kulturze popularnej, rozrywkowej. Pielęgnują wspólnotowość i wzajemne relacje w ramach kultury popularnej, gdzie mogą przeżywać i uczestniczyć jak Ukraińcy, zgodnie ze swoim skryptem kulturowym.

Każdy naród ma inny sposób celebrowania kultury. Językowy obraz świata, tradycje, historia, długość i szerokość geograficzna, na których przyszło im się wychowywać, predysponują użytkowników języka, sukcesorów tradycji itd. do określonej recepcji rzeczywistości. Sposoby regulacji jednostkowych i zbiorowych stanów emocjonalnych są warunkowane kulturowo. Przeżywanie kultury integruje imigrantów, a separuje ich od Polek i Polaków. Innymi słowy, jeśli uczestnictwo w kulturze polskiej w naszym kraju obejmuje kulturę wysoką, to Ukraińcy w ten sposób adaptują się do nowych warunków, do pełnoprawnego bycia w naszej kulturze, ale nie integrują z Polakami, gdyż ten poziom recepcji jest zbyt „wysoki” na współuczestnictwo. Kiedy z kolei Ukraińcy uczestniczą w kulturze niższej, popularnej, czynią to w swoim własnym gronie. Powstaje wówczas kultura paralelna do dominującej (praktykowanej przez Polaków) - konkultura.

\section{•...}

Kultura wysoka jest w naszym rozumieniu synonimem kanonicznej kultury narodowej, czyli tej, której uczy się w szkołach, pokazuje w muzeach i podstaw której znajomości wymaga się od cudzoziemców aspirujących do bycia członkami danego społeczeństwa. 
Konkultura zatem to jest zespół praktyk kulturowych inicjowanych przez grupę mniejszościową migrantów w nowym miejscu ich przebywania, które wynikają z narodowego skryptu kulturowego tej grupy. Grupa ta pielęgnuje w ten sposób wspólnotowość bez powiązania z kulturą dominującą (kulturą narodową) szerszego społeczeństwa, w skład którego wchodzą lub w przestrzeni którego żyją jej członkowie. Konkultura nie służy kultywowaniu tożsamości i cech dystynktywnych ani manifestowaniu odrębnego stylu życia, nie jest też przestrzenią emancypacji. Służy jedynie pielęgnowaniu wzajemnych relacji. Jednakże specyficzna dla niej separacja może w dłuższej perspektywie prowadzić do wrogości i antagonizmu.

\section{WSCHÓD VS. ZACHÓD}

Istnieje wiele różnic pomiędzy uczestnictwem w kulturze w Polsce i na Ukrainie. Nasi rozmówcy i rozmówczynie zwracają uwagę, że na Ukrainie uczestniczy się bardziej kolektywnie, biesiaduje się, rozmawia ze sobą. Na przykład we Lwowie kwitnie życie kawiarniane, ludzie spotykają się, śpiewają wspólnie, ale też uczestniczą w koncertach w kawiarniach. Wspólnotowość, waga tego, co się dzieje pomiędzy ludźmi większa niż wrażenia, jakie powstają pod wpływem dzieła, czyli więzi ważniejsze niż jednostkowe spełnienie to przymioty, które tradycyjnie przypisuje się kulturom Wschodu w odróżnieniu od Zachodu (Nisbett, 2009). Tak opowiada o tym jedna z badanych:

Zawsze z kimś się pogada, z kimś się przejdziesz na spacer. Zawsze w jakiejś kawiarni usiądziesz czy coś. Przy tym, że nawet poprzez to, że we Lwowie jest największe skupisko na metr kwadratowy kawiarni w całej Europie i tak czasami może nie być miejsca. Co jest fascynujące, naprawdę. Za każdym razem jak przyjeżdżam, to nowe i nowe kawiarnie są otwierane. Czyli no w pierwszą kolej kultura Lwowa polega na tym, żeby spotykać się ze znajomymi, rozmawiać, spacerować i odpoczywać właśnie w kawiarniach, przy dobrym jedzeniu. Nie ukrywam, że też przy dobrym piciu. Ale na przykład moja mama uwielbia chodzić do teatru. Znajoma jej zawsze załatwia bilety czy coś. Albo też wiele kawiarni mają coś takiego, że po prostu robią koncerty różne. I ona lubi chodzić do jednej kawiarni na koncerty jazzowe swoich znajomych, na przykład. [...] Polacy to „ooo chodźmy na imprezkę, chodźmy na imprezkę", ja myślę: „po co iść na imprezę, jeśli są ciekawsze metody odpoczywania i spędzania czasu z innymi ludźmi". Bo jednak kiedy na Ukrainie idą pić, bawić się to jednak podstawą jest komunikacja. Ludzie tam częściej rozmawiają ze sobą, a tutaj jak ludzie idą odpoczywać to zauważyłam, że przeważnie idą na imprezę. Na tańczenie i tak dalej. I to dla mnie, jeszcze będąc we Lwowie, to dla mnie było trochę dziwne (A_K_2).

Kolorytu miastom ukraińskim nadają sami twórczy Ukraińcy. Oni sami chcą tworzyć kulturę, nie tylko uczestniczyć w czymś, ale coś stwarzać. Badani opowiadają o tym, jak ulice Lwowa pełne są ulicznych artystów i na każdym kroku słychać muzykę. Młodzież chętnie angażuje się w różne twórcze przedsięwzięcia, zakładając zespoły, grając na instrumentach, śpiewając. Jedna z badanych bardzo ubolewa nad tym, że nie może się realizować w Warszawie, bo właśnie nie ma gdzie śpiewać². Prawdopodobnie imigrantom brakuje informacji o działających w Polsce (podobnie zresztą jak na Ukrainie) domach kul-

\section{$\cdots \cdots$}

2 O wadze śpiewu dla Ukraińców świadczą również wyniki badania Agaty Świdzińskiej (Świdzińska, 2019) przeprowadzone wśród ukraińskiej młodzieży uczącej się w szkołach średnich w Lublinie. Badani przez nią uczniowie, pytani o wartości podzielane przez kulturę polską i ukraińską, wymieniali m.in. sąsiedztwo, historię, język i wiarę. Jeśli zaś chodzi o to, co różni nasze dwie kultury, mówili o religii, zwyczajach i piosenkach(!). 
tury. Przed nami wypowiedź, która na to wskazuje, a zarazem pokazuje wspomniane już wyżej różnice kulturowe między naszymi krajami:

Nie macie tych normalnych takich kawiaren jazzowych. Są, ale no nie ma takich, że jest śpiew żywy, że coś takiego. Ja tyle razy tutaj byłam $w$ restauracjach, w cafe. $U$ nas jest tak, że śpiewają osoby na żywo, muzycy mają pracę. A tutaj tego nie ma! Tutaj jest zwykła muzyka, która jest zawsze tutaj puszczalna, ale no nie ma takiego żeby ktoś śpiewał i to było atrakcja jakaś... No, chociaż to jest stolica. U nas prawie każde kafeterium, każda kawiarnia jest po prostu z tym głosem, z tym śpiewem, z tą muzyką, z czymś takim pokazywane. No i to jest taką różnicą... Nie szukałam, już teraz nie szukałam z zajęć takich z wokalu, bo przestałam. Kilka miesięcy szukałam, bo właśnie teraz trochę ofiaruję z tego, bo ja strasznie chcę śpiewać i nie mam takiej możliwości [...]. Ja strasznie, jak kiedyś pierwszy rok byłam i strasznie płakałam, że tego nie mam, bo ja tak marzyłam o tym życiu studenckim, jakie jest u mnie w kraju, że są te konkursy, te wycieczki. Takie życie, wiesz, wycieczka w las, z tym ogniem, z tymi tańcami, z tym śpiewem, z tą muzyką, z tym wszystkim, bo my to mamy i tutaj tego nie ma. [...] To jest straszna różnica w życiu uniwersyteckim i to jest ból każdego Ukraińca, Rosjana i Białorusina, który tutaj przyjeżdża, że nie ma tego życia kulturalnego, które jest u nas. Właśnie tych konkursów. Czyli mogą być w niektórych uniwersytetach, ale nie ma tego tak za dużo, że sam uniwersytet daje pieniądze, chce tego, jakby zmusza, motywuje swoich uczniów do wyjawienia swoich talentów, do czegoś takiego (M_K_11).

W percepcji badanych na Ukrainie żyje się poza tym spokojniej. Ukraińcy się mniej spieszą, tam jakby czas płynie wolniej. Jak mówi jedna z nich:

W ogóle to Ukraińcy mają więcej czasu, moim zdaniem, niczym ja, bo ja i studiowałam i jeszcze pracowałam. Dlatego miałam bardzo mało czasu, ale chodzą do kina, chodzą do muzeum, no i tak (A_K_5).

Polska jest za to bardziej rozwinięta. Warszawa w porównaniu do Lwowa i Kijowa jest bardziej zachodnia, europejska, nowoczesna, ale przez to też bardziej indywidualistyczna i stateczna.

Nie no, dużo różnych wydarzeń, takich nowoczesnych nawet. Dlatego uważam, że jest więcej niż na Ukrainie, w Kijowie na przykład. Tam mniej tego wszystkiego jest. Ale tutaj jest bardziej takie kulturalne, a na Ukrainie jak jest takie wydarzenie to bardziej będzie takie dla młodzieży. Coś takiego rozrywka... jakiś spacer... coś takiego jak dla młodzieży. A tutaj bardziej plus 30, 40 lat. Ta mi się wydaje (M_M_5).

Ukrainki i Ukraińcy postrzegają Warszawę jako duże, wielokulturowe miasto, zwracają uwagę na jej rangę jako miasta stołecznego, szczycącego się bogatą, o wiele bogatszą niż na Ukrainie, ofertą kulturalną. Twierdzą, że w Polsce jest wszystkiego więcej, jest również lepszej jakości i bardziej zaawansowane technologicznie.:

Minus Ukrainy ogólnie i tego co w niej brakuje to muzea interaktywne, które są w Polsce. Tego na Ukrainie brakuje dlatego niestety nie mogę powiedzieć, że na Ukrainie ludzie często chodzą do muzea. To jest niestety nudne, nie jest to ciekawe i jest to trochę ubogo, ja bym powiedziała przedstawione. Takie bardzo zastarzałe, może nie ubogo ale zastarzało-to na pewno (A_K_2).

Wraz z głębszym poznawaniem Polski przychodzą czasem miłe (r)o(z)czarowania. Na przykład okazuje się, że Polska wcale nie jest taka konserwatywna, jakby się mogło wydawać. Jedna z badanych tak mówi o swoich wrażeniach:

- Tak. Klątwa, dlatego, że ja jak przyjechałam do Polski, to ja oczywiście poczytałam sobie trochę na temat tego kraju, że Polacy z reguły są bardzo religijni, trzymają się tradycji, może troszeczkę konserwatywni, ale w dobrym sensie tego słowa. No bo też kraj po takich przeży- 
ciach musi się trzymać jakoś, wspierać to jest jak najbardziej pochwalone przeze mnie i przez inne osoby też. No właśnie i zdziwiło mnie to, że nawet w takim kraju, który jest bardzo religijny znajdują swoje miejsce takie typu "Klątwa" no i w innych spektaklach też się to pokazuje, że Polska nie jest taka jednoznaczna, jednorodna jakby, i że można znaleźć dużo kontrowersyjnych rzeczy.

- A to pozytywne czy negatywne?

- Nie, pozytywne, głównie pozytywne. Wydaje mi się, że wszyscy ludzie są różni i nie można tak jakby szufladkować każdego po prostu wszystkich wrzucać do jednego wora, więc to jest bardziej w pozytywną stronę.

- Czyli to cię pozytywnie zaskoczyło, że kraj, o którym czytałaś, że jest takim krajem religijnym tradycyjnym, wystawia kontrowersyjne sztuki, to cię pozytywnie zaskoczyło?

- Tak oczywiście, bardzo. Bo ja uważałam... bo to jeszcze był taki bardzo kontrowersyjny film „Kler" na przykład i ja uważam, że to jest fajne, bo wiadomo, że pewne poglądy, czy tradycje nie zawsze mogą być tylko pozytywne, że mogą mieć też swoje negatywne cechy i uważam, że to jest bardzo dobre, że to się nie zamiata pod dywan, tylko to się wystawia, można się temu przyjrzeć, można trochę otworzyć się na to, że wszystko ma dwie strony akurat to mnie zaskoczyło jakby bardzo pozytywnie (U_K_1).

Polska jawi się wręcz jako miejsce, w którym przybysze otwierają się na to, co nowoczesne, awangardowe, nabierają większej śmiałości. Młodzi Ukraińcy mają tu duże możliwości poznawania różnorodnych form artystycznych, szeroki wachlarz, jeśli chodzi o tematykę, ogromne spektrum możliwości poszerzania zainteresowań kulturalnych. To sprzyja otwieraniu się i lepszemu poznawaniu samego siebie i swoich potrzeb. Tym bardziej że najczęściej trafiają tu w takim momencie życia, w którym wchodzą w dorosłość, zupełnie zmienia się ich sytuacja życiowa, mają poczucie niezależności, wolności i, co za tym idzie, większych możliwości. Bogata, różnorodna oferta kulturalna w połączeniu z tym poszukującym, a samodzielnym etapem życia sprzyja uczestnictwu i sprawia, że wygląda ono zupełnie inaczej niż wcześniej, na Ukrainie.

Tak, powiem tak zmieniło się, bo ja wcześniej tak jak mówię podziwiałam jakąś sztukę klasyczną to były pewne konkretne rzeczy, które już są przebadane przez pokolenia; nie wiem jak idziemy na przykład na jakąś wystawę to to jest Szekspir wiem, że to jest klasyk, że to jest sztuka natomiast potem jak przyjechałam do Warszawy to na przykład odwiedziłam centrum kulturowe Austrii tutaj obok jest na Świętokrzyskiej właśnie dom kulturowy Austrii. Odwiedziłam Muzeum Narodowe też Polski oczywiście tam są różne wystawy, ale też widziałam obrazy polskich malarzy bardzo mi się spodobało i jeżeli chodzi o jakąś inną sztukę to byłam też w teatrze współczesnym, gdzie na pewno to się różni od teatru klasycznego, bo tam nie ma takiej sceny podniesionej aktorzy nie są na górze tylko są na równi z widzami i na przykład czasami angażują nawet osoby z widowni (U_K_1).

Wydaje mi się, że tak troszeczkę się otworzyłem na to wszystko i zacząłem rozumieć co mnie interesuje, a co nie, w sensie jak widze jakiś tam nie wiem konkretne wydarzenie to wiem, że chcę na to pójść, a na przykład wcześniej po prostu mogłem na to popatrzeć i powiedzieć "a to ja nie wiem co to, to na to nie pójdę" w sensie bardziej się na to otworzyłem i wiem co mnie interesuje (A_M_2).

\section{ZAKOŃCZENIE}

Prezentowane wyniki badania mają charakter jakościowy, nie wynika z nich, ile spośród ukraińskich studentek i studentów w Polsce korzysta z kultury. Zdaniem naszych rozmówców tak naprawdę niewielka ich liczba, twierdzą, że mniej niż połowa, korzysta 
z oferty kulturalnej. Reszty to nie interesuje, nie chce im się, ale też mają inne priorytety. Istnieje również szereg obiektywnych barier, z których najważniejsze zostały omówione w niniejszych tekście, które prawdopodobnie jednak nie wyczerpują wszystkich możliwości odmowy uczestnictwa w kulturze. Formułowali je ci, którzy zgodzili się wziąć udział w badaniu i przez sam ten fakt należą do tych bardziej aktywnych. Szczegółowe rekomendacje dla Biura Kultury Urzędu m.st. Warszawy, z których korzystać mogą również włodarze innych miast w Polsce są dostępne w raporcie (Jawor i in., 2019). Natomiast dobrym zakończeniem będą słowa jednego z naszych badanych, który na pytanie: „A masz może jakiś pomyst, żeby zachęcić Ukraińców do korzystania z kultury?”, odpowiedział: „Takie wywiady" (A_M_50).

\section{BIBLIOGRAFIA}

Burszta, W. J. (1998). Antropologia kultury: Tematy, teorie, interpretacje. Zysk i S-ka.

Długosz, P. (2018). Integracja ukraińskich studentów podejmujących naukę w Polsce. Studia Migracyjne - Przegląd Polonijny, 44(2), 67-92. https://doi.org/10.4467/25444972S MPP.18.020.9146

Drozdowski, R., Fatyga, B., Filiciak, M., Krajewski, M., \& Szlendak, T. (2014). Praktyki kulturalne Polaków. Wydawnictwo Uniwersytetu Mikołaja Kopernika.

Grad, J. (1997). Badania uczestnictwa w kulturze artystycznej w polskiej socjologii kultury. Wydawnictwo Naukowe Uniwersytetu im. Adama Mickiewicza.

Jawor, A., Markowska-Manista, U., \& Pietrusińska, M. J. (2019). Bariery w korzystaniu z oferty warszawskich instytucji kultury przez młodych imigrantów z Ukrainy: Diagnoza - przyczyny - rekomendacje. https://cyfrowabiblioteka.um.warszawa.pl/files/original/79892f19b79fb1bb9184c7a107073823.pdf

Jawor, A., Markowska-Manista, U., \& Pietrusińska, M. J. (2020). Konkultura: Wymiary uczestnictwa w kulturze mtodych imigrantów z Ukrainy w Polsce. Wydawnictwo Naukowe Scholar.

Jędraszczyk, K., Krasiwski, O., Bezludny, O., Czmełyk, R., Durniak, B., Jaciw, R., Kotyhorenko, W., Stroński, H., \& Uhryn, J. (2016). Wychowanie i system oświaty na Ukrainie w latach transformacji ustrojowej. W K. Jędraszczyk (Red.), Społeczeństwo i kultura Ukrainy: Ćwierćwiecze przemian (1991-2016) (ss. 149-166). Instytut Kultury Europejskiej.

Kurczewska, J. (2000). Kanon kultury narodowej. W J. Kurczewska (Red.), Kultura narodowa i polityka (ss. 25-63). Oficyna Naukowa.

Nisbett, R. E. (2009). Geografia myślenia: Dlaczego ludzie Wschodu i Zachodu myślą inaczej? (E. Wojtych, Tłum.). Smak Stowa.

Przecławska, A. (1976). Zróżnicowanie kulturalne mtodzieży a problemy wychowania. Państwowe Wydawnictwo Naukowe.

Raport Studenci zagraniczni w Polsce 2018. (2018). Forum Akademickie. https://prenumeruj.forumakademickie.pl/fa/2019/02/kronika-wydarzen/studenci-zagraniczni-w-polsce-2018/\#

Świdzińska, A. (2019). Ukrainian students in Polish schools: Selected aspects of adaptation on the example of the city of Lublin. Kultura i Edukacja, 2019(4), 95-108. https:// doi.org/10.15804/kie.2019.04.06 